\title{
Penerapan Aseec Berbasis Energi Baru Terbarukan (Solar Cell) untuk Perontok dan Pengering Padi
}

\author{
Hendri $^{* 1}$, Aswardi ${ }^{* 2}$, Lian $^{* 3}$,Wirma ${ }^{* 4}$ \\ Teknik Elektro, Fakultas Teknik,Universitas Negeri Padang \\ KampusAirTawar,Padang25131,Indonesia \\ ${ }^{1}$ hendri97@gmail.com \\ ${ }^{3}$ lianabdiansyaheyahoo.co.id \\ ${ }^{4}$ wirmasisriegmail.com
}

\begin{abstract}
Abstrak - Dewasa ini kebutuhan akan beras semakin meningkat, sedangkan panen yang dihasilkan kurang optimal karena sering terjadinya susut hasil. Menurut Handaka (2007), titik kritis terjadinya susut hasil pada pemanenan padi, terutama pada pemotongan padi, pengumpulan potongan padi, dan proses perontokan. Aseec adalah jawaban yang tepat untuk mengatasi permasalahan ini. Aseec dikonstruksi hingga menjadi satu kesatuan utuh dengan ukuran yang relatif kecil dan relatif ringan sehingga dapat dipindahkan (portabel) dengan mudah dan sesuai dengan kondisi persawahan yang aksesnya susah dijangkau. Aseec merupakan teknologi yang ramah lingkungan karena menggunakan energi terbarukan yaitu sel surya sebagai sumber energi.Proses perencanaan Aseec ini dilakukan dengan tahapan yaitu perencanaan dan penjelasan fungsi, perencanaan konsep produk. Analisis teknik meliputi analisis daya, torsi yang terjadi pada poros dan motor penggerak dan konstruksi rangka. Hasil perencanaan menghasilkan rontokan padi $0,7 \mathrm{~kg}$ dalam 1 menit putaran 450 rpm. Tenaga penggerak Aseec menggunakan motor DC 24 V/4 A,torsi $25 \mathrm{~kg} / \mathrm{f} . \mathrm{cm}$ dengan putaran $500 \mathrm{rpm}$. Sistem transmisi menggunakan v-belt dengan poros penggerak $76,2 \mathrm{~mm}$. Konstruksi rangka terbuat dari besi profil $L 40 \times 40 \times 4 \mathrm{~mm}$ dan casing menggunakan besi plat dengan tebal $1,8 \mathrm{~mm}$ dan $1,5 \mathrm{~mm}$.
\end{abstract}

Kata kunci — Portabel, Otomatis, Solar Cell, Aseec

\section{INTRODUCTION}

Beras merupakan makanan pokok yang belum tergantikan sebagai kebutuhan primer masyarakat Indonesia. Bertambahnya penduduk maka kebutuhan akan beras semakin meningkat, sedangkan panen yang dihasilkan kurang optimal karena sering terjadinya susut hasil. Menurut Handaka (2007), titik kritis terjadinya susut hasil pada pemanenan padi, terutama pada pemotongan padi, pengumpulan potongan padi, dan proses perontokan. Menurut BPS (1988, 1996), masalah utama dalam penanganan panen padi adalah tingginya kehilangan hasil pasca panen serta gabah dan beras yang dihasilkan bermutu rendah. Hal ini terjadi karena tahapan pemanenan, perontokan, dan pengeringan yang kurang baik. Menurut Setyono
(2000), jumlah gabah yang tidak terontok berkisar antara $6,4-8,9 \%$ dari jumlah panen.

Program pemerintah juga mengusahakan Indonesia menjadi negara suasembada beras sehingga Indonesia tidak mengimpor beras dari negara lain. Pada tahun 1986, Presiden RI mengeluarkan Keputusan Presiden No. 47/1986 tentang Peningkatan Penanganan Pascapanen Hasil Pertanian. Hal ini menunjukkan besamya perhatian pemerintah terhadap upaya penyelamatan hasil panen. Sektor pertanian saat sekarang ini masih merupakan sorotan utama. Terbukti dengan banyaknya programprogram pertanian yang sedang dikembangkan. Seiring dengan itu muncul pemikiran-pemikiran untuk menyelesaikan permasalahan ini terutama pada bidang teknologi. Dewasa ini bermunculan berbagai teknologi pascapanen padi yang di titik beratkan pada proses pemanenan, perontokan, dan pengeringan. Namun, belum menemukan titik terang dalam pemecahan masalah ini, dimana teknologi yang di kembangkan dinilai kurang efektif dan efisien baik dalam segi rancangan, bahan bakar maupun hasil yang di dapat. Adapun teknologi yang sudah dikembangkan hanya mampu mengatasi sebagian dari permasalahan tersebut. Hal yang tidak kalah penting adalah kemampuan alat untuk dipindah-pindahkan (Portabel). Menurut Setyono (2006), ditinjau dari rendahnya susut hasil maka perlu adanya alat atau mesin perontok yang efektif dan efisien sehingga tidak terjadi penyusutan pada hasil panen serta harus ramah lingkungan.

Berdasarkan permasalahan yang tengah terjadi dan solusi yang telah ditawarkan maka dibutuhkan suatu teknologi yang tepat dalam meningkatkan hasil panen padi, mengatasi susut hasil, ramah lingkungan dan memiliki rancangan yang sesuai dengan kondisi persawahan. Sehingga Aseec adalah jawaban yang tepat untuk mengatasi permasalahan ini. Aseec dikonstruksi hingga menjadi satu kesatuan utuh dengan ukuran yang relatif kecil dan relatif ringan sehingga dapat dipindahkan dengan mudah dan sesuai dengan kondisi persawahan yang aksesnya susah dijangkau. Sehingga Aseec sangat memungkinkan untuk dipindah-pindahkan ke tempat yang diinginkan 
sehingga dapat memudahkan petani dalam memproses hasi panen. Aseec merupakan teknologi yang ramah lingkungan karena menggunakan energi terbarukan yaitu sel surya sebagai sumber energi. Aseec dirancang dengan penuh pertimbangan sehingga gabah dan beras yang dihasilkan bermutu tinggi dan dapat mengatasi kemungkinan susut panen.

"Aseec" (Automatic Seed Cleaner) : "Penerapan Aseec berbasis Energi Baru Terbarukan (solar cell) untuk perontok dan pengering padi". Aseec diharapkan mampu menjadi solusi yang efektif dan efisien dalam pemecahan masalah ini sehingga hasil panen masyarakat mendapatkan hasil yang lebih banyak sehingga mampu memenuhi kebutuhan akan beras. Aseec dipercaya mampu menyelesaikan permasalahan yang tengah terjadi tanpa harus takut akan dampak negatif yang di timbulkan akibat sampingannya, karena teknologi yang diterapkan jelas ramah lingkungan.

\section{METODE PENELITIAN}

Dalam menyelesaiakan kegiatan ini ada beberapa tahap yang akan dilakukan meliputi :

A. Studi pustaka

Studi pustaka dilakukan berdasarkan pada bukubuku referensi yang bertujuan untuk memperkuat materi pembahasan maupun sebagai dasar untuk menggunakan rumus-rumus tertentu dalam menganalisa dan mendesain suatu alat.

B. Observasi lapangan

Tujuan umum melakukan observasi lapangan adalah mengamati secara langsung di alam terbuka untuk mencari suatu kebenaran tentang sesuatu yang ingin dicocokkan dengan nalar pikiran manusia sehingga dapat dipertanggung jawabkan dan menjadikan kebenaran itu suatu fakta dan benar. Kegiatan pengamatan dilakukan guna menggali dan mengumpulkan data yang diperlukan bagi topic pembahasan guna pengembangan wawasan dan peningkatan kinerja.

C. Perancangan

Perancangan dilakukan dengan menggambar alat terlebih dahulu yang dibuat di softwareAutocad.

D. Pembuatan

Setelah tahap perancangan, akan dilakukan pembuatan alat dengan mengukur dan memotong bahan sesuai dengan perencanaan

E. Pengujian.

Setelah alat telah selesai dibuat, maka akan dilakukan pengujian yang bertujuan untuk mengetahui apakah alat telah bekerja dan siap digunakan

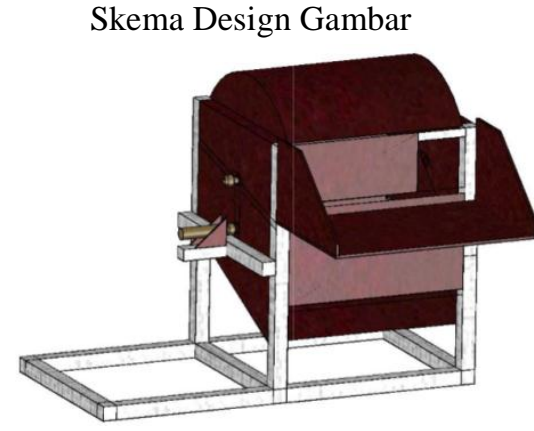

Gambar 1. Design Gambar Alat

Dalam menyelesaiakan kegiatan ini ada beberapa tahap yang dilakukan meliputi :

A. Studi pustaka

Studi pustaka dilakukan berdasarkan pada bukubuku referensi yang bertujuan untuk memperkuat materi pembahasan maupun sebagai dasar untuk menggunakan rumus-rumus tertentu dalam menganalisa dan mendesain suatu alat.

B. Observasi lapangan

Tujuan Umum melakukanObservasi lapangan adalah mengamati secara langsung dialam terbuka untuk mencari suatu kebenaran tentang sesuatu yang ingin dicocokkan dengan nalar pikiran manusia sehingga dapat dipertanggung jawabkan dan menjadikan kebenaran itu suatu fakta dan benar. Kegiatan pengamatan dilakukan guna menggali dan mengumpulkan data yang diperlukan bagi topic pembahasan guna pengembangan wawasan dan peningkatan kinerja.

C. Perancangan

Perancangan dilakukan dengan menggambar alatterlebih dahuluyang dibuat disoftware Autocad.

D. Pembuatan

Setelah tahap perancangan, akan dilakukan pembuatan alat dengan mengukur dan memotong baan sesuai dengan perencanaan

E. Pengujian.

Setelah alat telah selesai dibuat, maka akan dilakukan pengujian yang bertujuan untuk mengetahui apakah alat telah bekerjadan siap digunakan

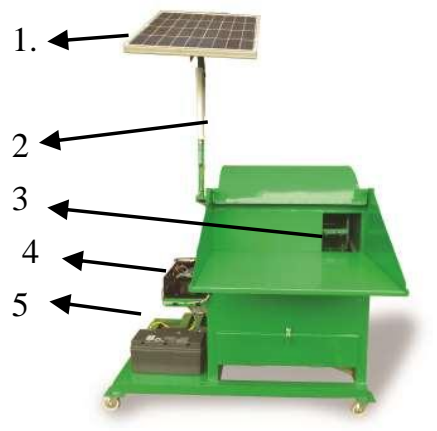

Gambar 2. Perencanaan alat 
Keterangan :

1. Solar cell

2. Lampu penerangan

3. Pemasukan Gabah

4. Kontrol

5. Baterai

\section{METODE PERENCANAAN}

A. Perencanaan Daya Motor

Daya motor merupakan daya yang dapat menggerakkan perontok dengan pertimbangan gaya yang bekerja pada poros. Daya motor yang akan direncanakan dapat digunakan rumus [elemen mesin,1980,16]

$$
\begin{aligned}
& \mathrm{P}=\frac{2 \pi \mathrm{NT}}{60} \\
& \text { Keterangan }: \\
& \mathrm{P}=\text { daya }(\mathrm{W}) \\
& \mathrm{N}=\text { putaran pully }(\mathrm{rpm}) \\
& \mathrm{T}=\text { torsi }(\mathrm{N} . \mathrm{m})
\end{aligned}
$$

Untuk menghitung daya motor (Pd) terlebih dahulu dihitung torsinya $(\mathrm{T})$ yaitu:

$$
\mathrm{T}=\mathrm{F} \times \mathrm{R}
$$

Keterangan :

$\mathrm{F}$ = gaya potong $(\mathrm{Kg})$

$\mathrm{R}=$ titik potong terluar $(\mathrm{m})$

Setelah mengetahui besarnya torsi yang dihasil maka daya motor dapat dihitung dengan

$$
\mathrm{Pd}=\mathrm{T} \times \omega
$$

$\omega=2 \times \pi \times n$

\section{B. Perencanaan Poros}

Poros merupakan salah satu bagian yang penting karena berfingsi sebagai kedudukan perontok.

a. Menghitung momen yang terjadi pada poros yaitu [elemen mesin, 1980,16]

$$
\mathrm{T}=9.74 \times 10^{5} \mathrm{v}
$$

b. Menghitung diameter poros

$$
\mathrm{D}_{\mathrm{S}}=\left[\frac{5.1}{T} K t . C b . T\right]^{1 / 3}
$$

Keterangan :

$\mathrm{Kt}=$ faktor koreksi

$\mathrm{Cb}=$ faktor koreksi lenturan

C. Perencanaan Pully

Kecepatan pully sangat dipengaruhi oleh putaran motor. Adapun rumus untuk menghitung kecepatan pully yaitu [elemen mesin II,1982,35]

$\mathrm{V}=\frac{\pi \mathrm{dpn}}{60}$

Keterangan :

$\mathrm{V}=$ kecepatan pully

$\mathrm{Dp}=$ diameter pully

$\mathrm{N}=$ putaran pully

D. Perencanaan Sabuk (V-Belt)
Perhitungan yang digunakan dalam perancangan sabuk yaitu : [elemen mesin II,1982,34]

a. Perbandingan Transmisi

$\frac{n 1}{n 2}==\frac{d 2}{d 1}$

Keterangan :

$\mathrm{n} 1=$ putaran poros pertama $(\mathrm{rpm})$

$\mathrm{n} 2=$ putaran poros kedua $(\mathrm{rpm})$

$\mathrm{d} 1=$ diameter pully penggerak $(\mathrm{mm})$

$\mathrm{d} 2=$ diameter pully yang digerakkan $(\mathrm{mm})$

b. Menentukan kecepatan linear sabuk

$\mathrm{V}=\frac{\pi \cdot \mathrm{d} \cdot \mathrm{n}}{60.100}$

c. Menentukan panjang sabuk

$\mathrm{L}=2 \mathrm{C}+\frac{\pi}{2}(\mathrm{dp}+\mathrm{Dp})+\frac{1}{4 . C}(\mathrm{Dp}-\mathrm{dp})^{2}$

Keterangan :

$\mathrm{L}=$ panjang sabuk $(\mathrm{mm})$

$\mathrm{C}=$ jarak sumbu poros $(\mathrm{mm})$

$\mathrm{Dp}=$ diameter pully penggerak $(\mathrm{mm})$

$\mathrm{Dp}=$ diameter pully poros $(\mathrm{mm})$

\section{E. Kontrol Sistem Aseec}

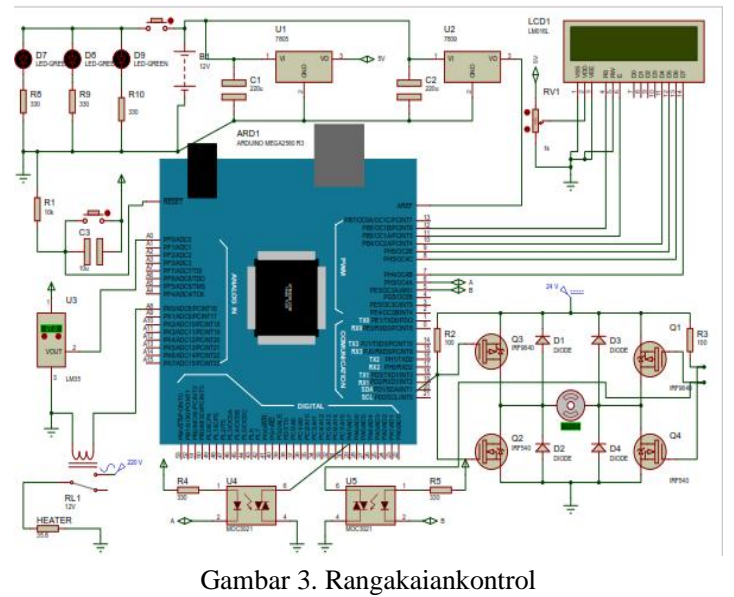

\section{HASIL DAN PEMBAHASAN}

A. Uji kelayakan

Adapun tujuan dilakukannya pengujian alat ini adalah untuk mengetahui berapa besar tingkat efisiensnya apakah sudah berhasil dan sesuai dengan yang diharapkan. Adapun hal-hal yang perlu diperhatikan sebelum melakukan proses pengujian adalah

a. Memeriksa kondisi apakah sudah dalam keadaan baik.

b. Apakah pully sudah terpasang dengan kuat pada motor dan poros

c. Apakah sabuk sudah terpasang dengan baik pada pully motor dan pully poros

Alat dan bahan yang digunakan dalam pengujian ini adalah,

a. Mesin perontok padi

b. Padi dan jerami 


\section{B. Hasil Pengujian}

Berikut ini adalah hasil pengujian alat ini

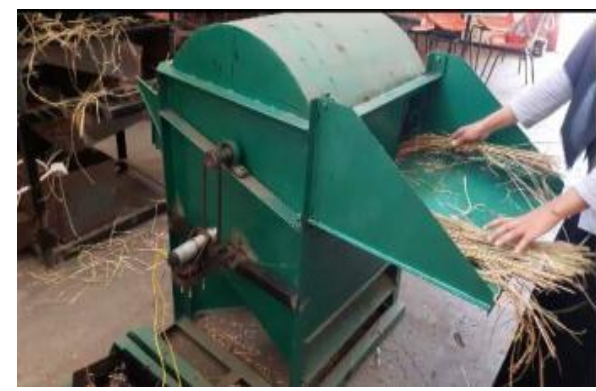

Gambar 4. Hasil pengujian

TABEL I

HASIL PENGUJIAN

\begin{tabular}{|c|c|c|c|}
\hline $\begin{array}{c}\text { Jumlah } \\
\text { padi }(\mathrm{Kg})\end{array}$ & $\begin{array}{c}\text { Putaran } \\
\text { pada poros } \\
(\mathrm{rpm})\end{array}$ & $\begin{array}{c}\text { Waktu } \\
\text { (menit) }\end{array}$ & $\begin{array}{c}\text { Hasil } \\
\text { rontokan } \\
\text { padi }(\mathrm{Kg})\end{array}$ \\
\hline 1.5 & 450 & 1 & 0.7 \\
\hline
\end{tabular}

\section{DAFTAR PUSTAKA}

[1] Handaka. 2007. Sistem Kontrak Kerjadan Pilihan Mekanisasi Pasca Panen Padi, Seminar dan Diskusi Pasca Panen Padi, BBP. Mekanisasi Pertanian, Serpong, 31Oktober

[2] Jazi, IstiyantoE. 2014. Pengantar Elektronika dan Instrumentasi:Pendekatan Project Arduino \& Android. Yogyakarta : Penerbit Andi

[3] Syahwil, Muhammad. 2013. Panduan Mudah Simulasi dan Praktik Mikrokontroller Arduino. Yogyakarta: Penerbit Andi.

[4] Rahul Malhotra.2011."Dc Motor Control Using Fuzzy Logic Controller".(IJAEST) InternationalJournalOf Advanced Engineering Sciences And Technologies Vol No.8, Issue No.2, 291-296

[5] Resmana. 1999. "Implementasi Fuzzy Logic Pada Microcontoller Untuk Kendali Putaran MotorDC", Proceedings, Industrial Electronic Seminar1999(IES'99), Graha Institut Teknologi Sepuluh Nopember, Surabaya, October 27-28,1999

[6] Setyono,A., Sutrisnodan S.Nugroho. 2000. Pemanenan PadiSistemKelompokdengan Memanfaatkan Kelompok Jasa PemanendanJasa PerontokDisampaikanpada Apresiasi Seminar Hasil Penelitian Balitpa. Sukamandi 10-11 November2000

[7] Sigit Nugraha, "Metode Menekan Kehilangan Hasil Padi".Balai Besar LitbangPascapanen Pertanian Jl. Tentara Pelajar 12 KampusCimanggu, Bogar

[8] Sritomo W.Soebroto. "Modifikasi Rancangan Mesin Perontok Padi Dengan Pendekatan ErgonomiAntropometri". Laboratorium argonomi \& Perancangan Sistem Kerja Jurusan Teknik Industri Institut Teknologi Sepuluh Nopember Kampus ITS-Sukolilo, Surabaya 60111 PhIFax: (031)-5939361,5939362; 